or squeezed out of the intensely sheared roots of growing mountain ranges; or they may have a source of some quite unsuspected kind. But our ignorance of the source of orogenic emanations in no way militates against the evidence of their passage through the rocks. The origin of basaltic magma remains equally uncertain, despite many optimistic suggestions to the contrary. Read quotes with approval Kennedy's recognition (1938) of two contrasted expressions of magmatic activity, distinguished respectively as :

(a) volcanic associations, derived from a parental basaltic magma which originates by the remelting of the earth's basaltic layer; and

(b) plutonic associations, derived from a parental granodioritic magma which originates where tectonic thickening of the crust brings the 'granite' layer within the range of melting; the ascent of such magma is preceded by an advancing wave of granitization and migmatization.

Since 1938, more precise estimates have been made of the heat generated in rocks by radioactivity, and of the crustal heat flow that escapes at the surface in Britain, South Africa and eastern North America. The results imply that in these non-volcanic regions the normal granitic and basaltic layers fall short of the temperatures required for magma formation by several hundreds of degrees'. In the light of the evidence now available, we can do no more than speculate as to how basaltic magma comes into existence. Where the granitic layer is greatly thickened in the roots of mountain ranges, the temperature at the base might eventually rise to the point required to start selective fusion, but many millions of years would be required, and even then latent heat would have to be supplied. The suggested process therefore fails to account for the observed fact that granitic rocks began to be formed (at levels well within the range of subsequent denudation) while the orogenic movements were actively in progress. Thus the whole problem of magma generation, apart from the possibilities associated with the emanation hypothesis, is still as baffling as ever.

There remains for consideration the all-important space problem : How have large masses (batholiths) of granitic rocks come to occupy their present positions, and what has happened to the rocks that were previously there? The bodily intrusion of gigantic volumes of magma appears to be mechanically impossible; and, as Read puts it: "The only solution is to suggest that in fact no large bodies of granitic magma were in existence. The large granite masses result from replacement, they are granitization products. Many of the small granites may of course also be of the same origin, but some of them may result from the consolidation of migma and some from the consolidation of magma. Thus, though there may be granites and granites, most of them are of one kind and all of them may likely be of one connected origin." With this conclusion I am in full agreement.

${ }^{1}$ Iddings, J. P., Bull. Phil. Soc. Washington, 12, 91 (1892).

"Read, H. H., "Meditations on Granite: Part I", Proc. Geol. Assoc., 54, 64 (1943); Part II, ibid., 55, 45 (1944).

- Green, A. H., Geol. Mag., 8, 428, 553 (1871)

- Callaway, C." Quart. J. Geol. Soc., 41, 221 (1885).

s Rosenbusch, F., Ahh. Geol. Spezialkarte Flsass-Lothr., 1, 80 (1877).

- Cole, G. A. J., Quart. J. Geol. Soc., 71, 184 (1915).

7 Reynolds, D. L., Proc. Roy. Irish Acad., 48 B, 231 (1943); Quart. J.

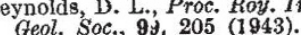

B Reynolds, D. L., Quart. J. Geol. Soc., 97, 1 (1941). Walker, F., and Poldervaart, A., Trans. Roy. Soc. S. Africa., 29, 285 (1942)

- Holmes, A., "Principles of Physical Geology", 480-483 (Edinburgh, $1944)$.

References already given by Read (see ref. 2) have not been repeated the above are additional.

\section{VARIATIONS IN THE COMPOSITION OF THE SEA IN WEST AFRICAN WATERS}

\author{
By DR. G. R. HOWAT \\ Government Chemist, Accra
}

Trentio HERE appears to be very little published scientifio information about the chemical characteristics and plankton content of the sea along the West African coast except for observations made by various scientific expeditions passing through these waters, and there appears to be no published data in English of continuous observations made over a prolonged period. An opportunity to make such observations presented itself in 1943 and 1944, arising out of a scheme by the Gold Coast Government to develop the local fishing industry; and an attempt has been made to obtain some information of the variations occurring throughout the year in the chemical composition and plankton content of the inshore waters of the Gold Coast Colony. As no suitable craft was available for going far out to sea, the samples were taken at a point about one and a half miles from the shore in a depth of eight fathoms of water off Accra, the capital of the Colony. Samples were taken each week (with one or two exceptions) from the beginning of June 1943 to the end of September 1944. One sample was taken for chemical examination and one for a rough examination of the quantity and general character of the plankton content; both samples were taken 5-6 feet below the surface. The temperature of the samples was taken at the time of sampling, and salinity, dissolved oxygen, and phosphate were estimated in the laboratory. These results are shown graphically in Figs. 1 and 2.

From Fig. 1 it will be seen that during this period the variation in temperature exceeded $10^{\circ} \mathrm{C}$. The highest temperature recorded was $29 \cdot 4^{\circ} \mathrm{C}$. on May 13,1944 , and the lowest was $19^{\circ} \mathrm{C}$. on August 3, 1943. The lowest temperature recorded in 1944 was $19 \cdot 8^{\circ} \mathrm{C}$. on August 18. The relatively sudden and wide variations in temperature which occur between June and October are presumably a causative factor in the sessonal nature of the fishing in the waters of the Colony. As might be expected, the figures for the salinity $(5 \%)$ given in Fig. 1 do not, with one exception, show any wide variations; but there is a slight increase observed in August and September both in 1943 and 1944. The rather low salinities observed at the beginning of July 1943 occurred at times of heavy rain.

The one wide variation referred to above occurred at the end of January and the beginning of February 1944. At that time the salinity fell from 33.93 on January 25 to 30.05 on February 9 , and then rose sharply again to 34.95 on February 22 . This very sudden fall is difficult to explain. It occurred at a time when there was no rain in the Accra district or along the coast. At this time, however, there was a strong east-to-west current and the only reasonable assumption is that large volumes of water from the River Volta formed a surface current which flowed westward as far as Accra.

The figures for the dissolved oxygen shown in Fig. 2 are the amounts of oxygen expressed as the percentage saturation. The figures show a surprising consistency during the greater part of the year. From the middle of October 1943 to the middle of July 1944 the saturation never exceeded 100 per cent or fell below 94 per 


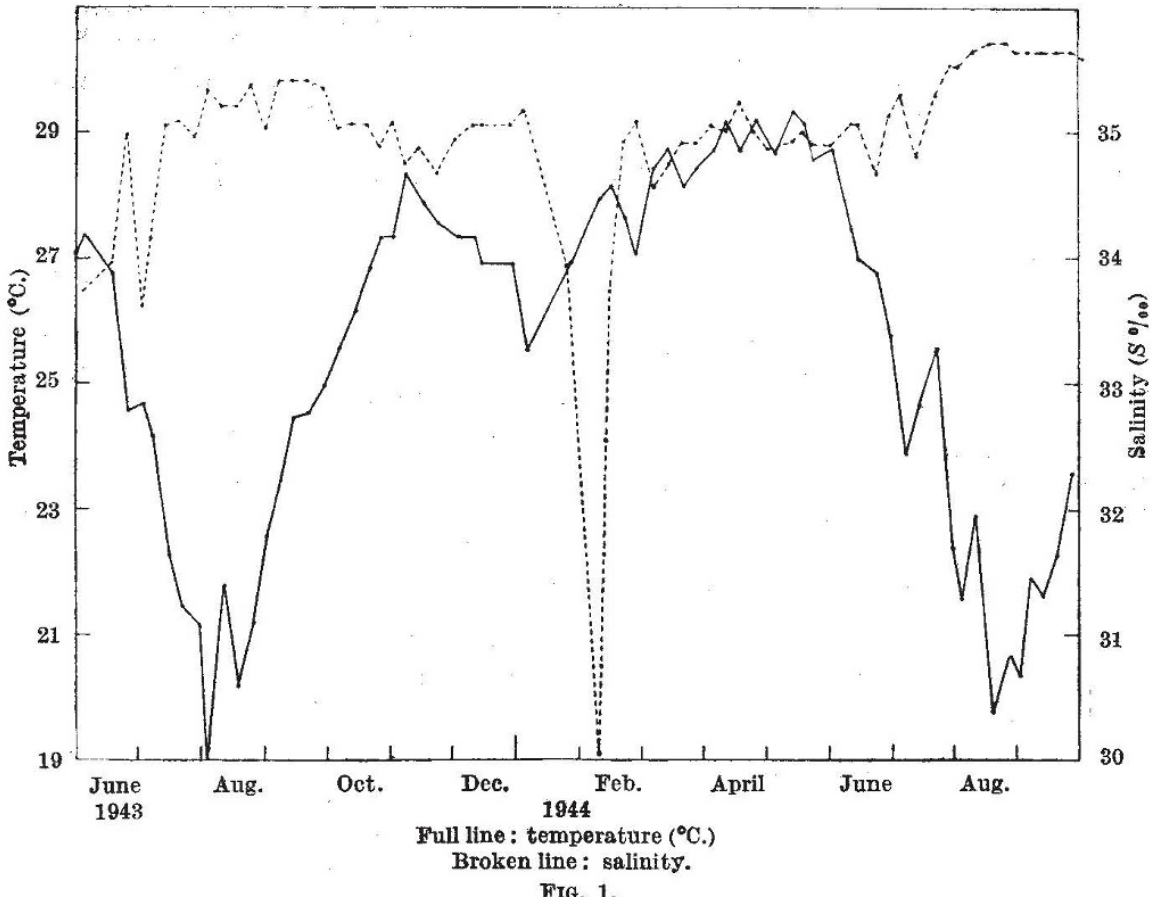

FIG. 1.

cent. The latter part of July, August and September brought wide variations both in 1943 and 1944 .

The figures for the phosphate content given in Fig. 2 are the amounts of phosphate calculated as $\mathrm{P}_{2} \mathrm{O}_{5}$ per cubic metre. It will be observed that from the beginning of January to the end of March 1944 the amount of phosphate remained almost at zero, while July, August and September in both years saw moderately high values. The densities of the samples were determined at $80^{\circ} \mathrm{F} .\left(26 \cdot 7^{\circ} \mathrm{C}.\right)$; the highest value was $1.0268\left(80^{\circ} / 80^{\circ}\right)$ on September 19 and 27,1944 , and the lowest was $1.0226\left(80^{\circ} / 80^{\circ}\right)$ on February 10, 1944.

As no trained marine biologist was available to undertake full examination of the plankton samples, their investigation was not so complete as could be desired; so only certain broad generalizations can be made. The vegetative plankton was found to consist of diatoms, chiefly Chatoceros spp., Coscinodiscus spp., and Rhizosolenia spp., and dinoflagellates such as Ceratium spp. and Dinophysis sp. The animal plankton consisted almost entirely of crustaceans and Sagitta sp. The crustaceans were mostly various species of copepods, but numbers of the larval forms of larger crustaceans were found. several species of echin.

FIG. 2. oderm larvæ were also taken in the tow-net, and on one or two occasions fish eggs were seen.

It was found that the character of the plankton samples changed considerably during the period under review. In June 1943 the samples were moderate in quantity and were composed chiefly of copepods and Sagitta sp. In July, August, and part of September 1943, the samples consisted almost entirely of diatoms, chains of Chotoceros spp. being specially abundant. After the end of September, apart from a few Coscinodiscus spp., practically no diatoms were observed, the semples being composed of copepods and Sagitta sp. In January, February and March 1944 the samples were, generally, poor in quantity and were composed chiefly of copepods and a few Sagitta sp. In April and May the quantity was generally larger and the samples were again composed of copepods and Sagitta sp. with a number of larval medusæ. At the beginning of June, diatoms began to appear in some quantity, although the catch was still composed chiefly of copepods. Later on in the month Coscinodiscus sp. and Ceratium spp. were also present, again with a large number of copepods. In July the quantity of the samples was considerably larger, and by the end of that month there were only a few copepods present and the bulk of the catch was Coscinodiscus sp. and chains of Chatoceros spp. During this month, too, a considerable number of echino-

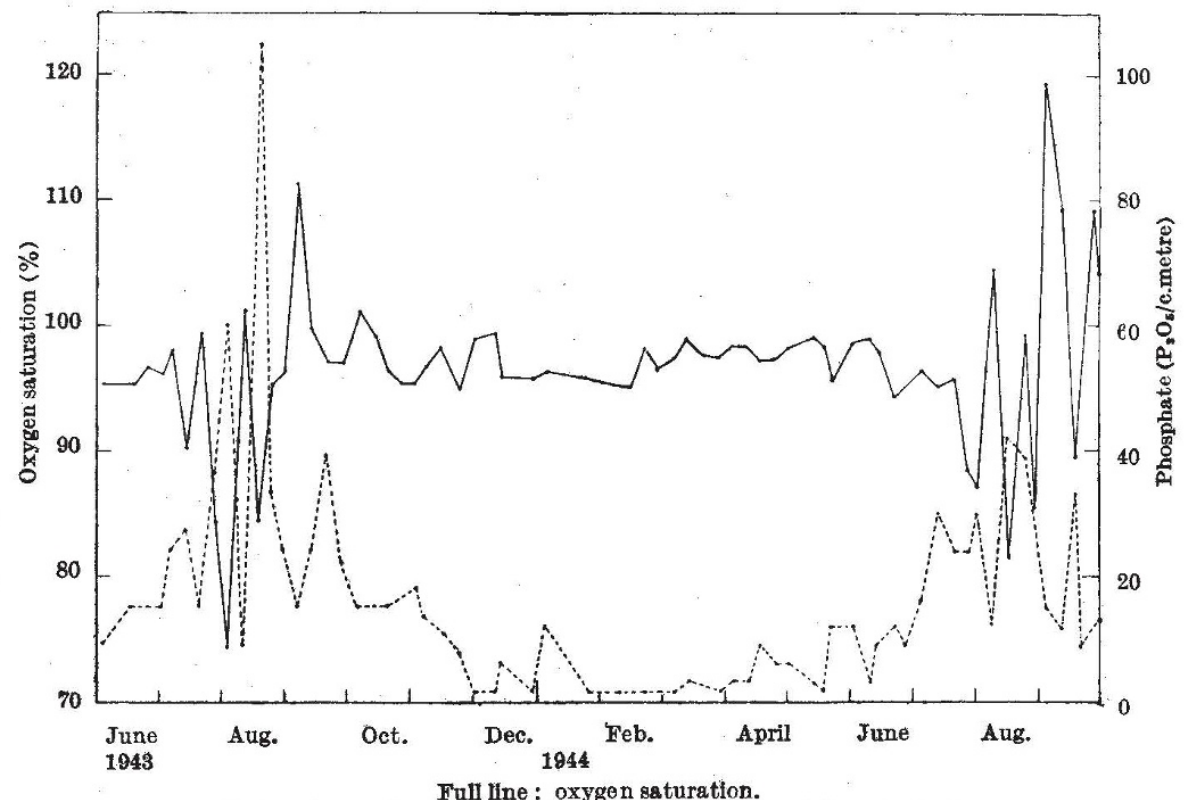

Broken line : phosphate per cubie metre (uncorrected for salt error). 
derm larvæ were observed. The character of the samples remained the same during the first part of August, but in addition some Rhizosolenia spp. (?) were observed. On August 16 a very unusual phenomenon was observed when taking the water sample. The sea was found to be a distinct chocolate-brown colour and very turbid. A sample was taken in a glass jar and the colour was seen to be due to vast numbers of a small greenish-brown organism just sufficiently large to be distinguished by the naked eye. Examination in the laboratory later on showed it to be a flagellated organism, which I was unable to identify. The plankton sample consisted almost entirely of masses of this organism. I do not know how far the coloration extended, but it was observed from aircraft for at least 70 miles along the coast. 'The phenomenon persisted for days, and when the next weekly sample was taken there were still masses of the organism in the plankton sample. During the first part of September Coscinodiscus sp. and Choetoceros spp. composed the bulk of the catch, and later on Noctiluca sp. (probably N. scintillans) predominated.

An examination of the data obtained from the samples appears to indicate that there is an influx of cold ocean water along the sea-board of the Colony during the months of July, August and September. This may be due to an upwelling of deep ocean water on to the continental shelf, or to cold ocean water from the South Atlantic Ocean finding its way into the current which flows for the greater part of the year from west to east along the sea-board of the Colony. It is probably not without significance that this influx of cold water, slightly more soline and richer in phosphate, coincides roughly with the main fishing season along the greater part of the coast of the Colony, when two species of Sardinella- $S$. aurita and $S$. cameronensis-are caught in large quantities.

It is hoped to continue and extend this work in the near future.

\section{THE PUBLIC SCHOOLS OF BRITAIN}

\section{By the Rev. CANON SPENCER LEESON Headmaster, Winchester College}

$\mathrm{T}$ HE public schools question has been somewhat in abeyance in recent months. Among the reasons for this is that the larger share of public attention in this province has been given to the Education Act, and the numerous administrative measures that are required to bring it into effective operation; and also that up to now the negotiations between the Ministry, on one hand, and the associations of governing bodies for boys' schools and girls' schools, the headmasters and headmistresses on the other, have been confined to scheme $A$ of the Fleming Report, that is, the recommendations applying to what will be known in the future as direct-grant grammar schools. These negotiations are pretty well completed, and the revised regulations for directgrant grammar schools have now been published. Discussions on scheme $B$, that is, those recommendations that affect mainly the independent boarding schools and day schools, are just beginning; and we may therefore expect a revival of public interest in the future of those schools.

The Fleming Committee is to be warmly congratu- lated on producing a unanimous report on so difficult and controversial a question; and its whole discussion of the matter and its recommendations are clearly based on a wide and deep knowledge of conditions prevailing in the schools, and the concrete problems that have to be solved. Various proposals were put before them for the future regulation of the public schools. One extreme view was that they should be abolished altogether, their endowments taken over and their buildings dedicated to other educational purposes, hostels, residential courses in adult education and so forth. It is not likely that this view will be supported in any responsible quarter. Another suggestion was that the schools should be kept in operation, but should be handed over to the State to be run as part of the State educational service, boys and girls being allocated to them by public authority, and the schools being brought under full public control. The third proposal is that put forward by the Fleming Committee, namely, that the schools should remain independent, although open to inspection by the Ministry of Education and accepting to membership of their governing bodies public representatives up to not more than one third of the total number; and that they should reserve each year 25 per cent of their admissions for boys and girls who have previously been educated at primary schools, the expense, as calculated on a fee to be agreed upon for each school between the schools and the Ministry, to be met from public funds in so far as the parents themselves are unable to pay the full cost. It is around these recommendations that, no doubt, the coming negotiations will centre; and we may hope that in a few months some measure of agree. ment will be reached. It is made clear in the report that the co-operation of the schools is to be voluntary from their side and that no compulsion should be applied to them.

I submit that in the settlement of this great national question we should endeavour to free ourselves from political preconceptions and prejudice on both sides. History shows that politics is no friend to education, and that where political considerations and especially party considerations are allowed to come in from either end, the work of the schools suffers. I suggest that we should put all this on one side and base ourselves on two propositions. The first is contained in section 76 of the Education Act, 1944 : ... "In the exercise and performance of all powers and duties conferred and imposed on them by this Act, the Minister and Local Education Authorities shall have regard to the general principle that, so far as is compatible with the provision of efficient instruction and training and the avoidance of unreasonable public expense, pupils are to be educated in accordance with the wishes of their parents". The second proposition is contained in the first recommendation on p. 100 of the Fleming Report ... "that opportunities of education in the schools included in our terms of reference (i.e., roughly speaking, the public schools), and in any such other schools as may be approved for the purpose by the Ministry of Education, be made available to boys and girls capable of profiting thereby, irrespective of the income of their parents". No considerations other than these have really any bearing on the matter. If it is argued that ex-primary pupils should be taken into the schools at public expense in order to preserve the latter from extinction, that argument has no validity; if the schools cannot stand on their own feet, they had much better disappear. On the 